\title{
Spirura carajaensis n. sp. (Nematoda: Spiruridae), parasite of Proechimys roberti Thomas 1901 (Rodentia: Echimyidae) from Brazilian Amazon
}

\section{H. DA COSTA CORDEIRO ${ }^{1}$, F. TIAGO DE VASCONCELOS MELO ${ }^{1}$, A. MALDONADO JR. ${ }^{2}$, J. NASCIMENTO DOS SANTOS ${ }^{*}$}

\author{
1Laboratory of Cell Biology and Helminthology "Profa. Dra. Reinalda Marisa Lanfredi" (Laboratório de Biologia Celular \\ e Helmintologia "Profa. Dra. Reinalda Marisa Lanfredi"), Institute of Biological Sciences (Instituto de Ciências Biológicas), Federal \\ University of Pará (Universidade Federal do Pará - UFPA), Belém, Pará *E-mail: jeannie@ufpa.br ; 2Biology and Parasitology \\ of Sylvatic Mammals and Reservoirs Laboratory, Oswaldo Cruz Institute, Oswaldo Cruz Foundation, Brazil
}

\section{Article info}

Received April 16, 2014

Accepted September 23, 2014

\begin{abstract}
Summary
A new species of nematode, from the family Spiruridae, is described using parasites from the esophageal mucosa of Proechimys roberti (Rodentia: Echimyidae), which were obtained during a fauna survey in the Tapirapé-Aquirí National Forest, Carajás Reserve, Brazil, Eastern Brazilian Amazon. The helminthes were collected from the esophagus, fixed and processed for light microscopy. Spirura carajaensis n. sp. differs from other species in the genus because it has a left spicule with a welldeveloped sheath, which is leaf-shaped and covers the terminal half of the spicule. Males and females have a small appendix on the caudal end. This structure has not been reported before for this genus. The present study reports the first record of parasitism by Spirura in rodents of the genus Proechimys in Brazil and in the Amazon biome.
\end{abstract}

Keywords: Spirura; Spirura carajaensis; Proechimys; Amazon; Brazil

\section{Introduction}

The genus Proechimys (Rodentia: Echimyidae) comprises 16 species of rodents in Brazil, with at least 5 species occurring in the Brazilian Amazon (Bonvicino et al., 2008). In the state of Pará (Eastern Amazon), Bonvicino et al. (2008) reported the occurrence of $P$. curviere, $P$. goeldi and $P$. guianensis species, while Weksler et al. (2001) additionally revealed the presence of $P$. roberti and $P$. oris. These rodents are terrestrial and can be found in forested areas of the Amazon, gallery forests and semi-deciduous forests in the Cerrado biome (Bonvicino et al., 2008). Such species are of public health interest in Brazil because they are reservoirs of Leishmania sp. and Trypanosoma sp. (Barretto et al., 1985). However, there have been few studies examining their helminth fauna.

According to Anderson (2009), the nematodes of the family Spiruridae (Oerley, 1885) are distributed in 3 genera (Paraspirura (Sandground, 1936), Spirura (Blanchard, 1849), and Protospirura (Seurat, 1914)). Currently, approximately 26 mammalian parasite species are known in the genus Spirura, with a cosmopolitan distribution (Peralta-Rodriguez et al., 2012).

In Brazil, only 2 of these genera have been recorded as parasites of mammals: Protospirura and Spirura (Vicente et al., 1977), and the authors list three species of the genus Spirura that are parasites of Brazilian mammals. However, only Spirura delicata (Vi- cente et al., 1992) was identified as a primate parasite in the Amazon biome, and Spirura guianensis (Ortlepp, 1924) (syn. Spirura tamarini Cosgrove et al., 1963) was identified to infect marsupials in the Atlantic Forest biome (Amato et al., 1976). This study aims to add new data to the nematode fauna of the rodent $P$. roberti in the Amazon biome and describes a new spirurid species. In addition, this study reports for the first time the parasitism of Spirura in $P$. roberti, which is a new a host for the genus in Brazil.

\section{Material and Methods}

The digestive tract samples from the 9 specimens of Proechimys roberti collected in the Tapirapé-Aquirí National Forest analyzed in this study were kindly donated by Dr. Rogério Rossi and were fixed in $10 \%$ formaldehyde. These samples were analyzed in the Cellular Biology and Helminthology Laboratory (Laboratório de Biologia Celular e Helmintologia - LBCH) at the Biological Sciences Institute, Federal University of Pará (Universidade Federal do Pará - UFPA) to investigate the presence of helminthes.

The nematodes were removed from the mucosa of the esophagus, where they were attached. After removal, they were processed in increasing grades of ethanol and clarified in Aman lacto-phenol. The morphological analysis and identification of taxonomic characters were performed under an Olympus BX41 

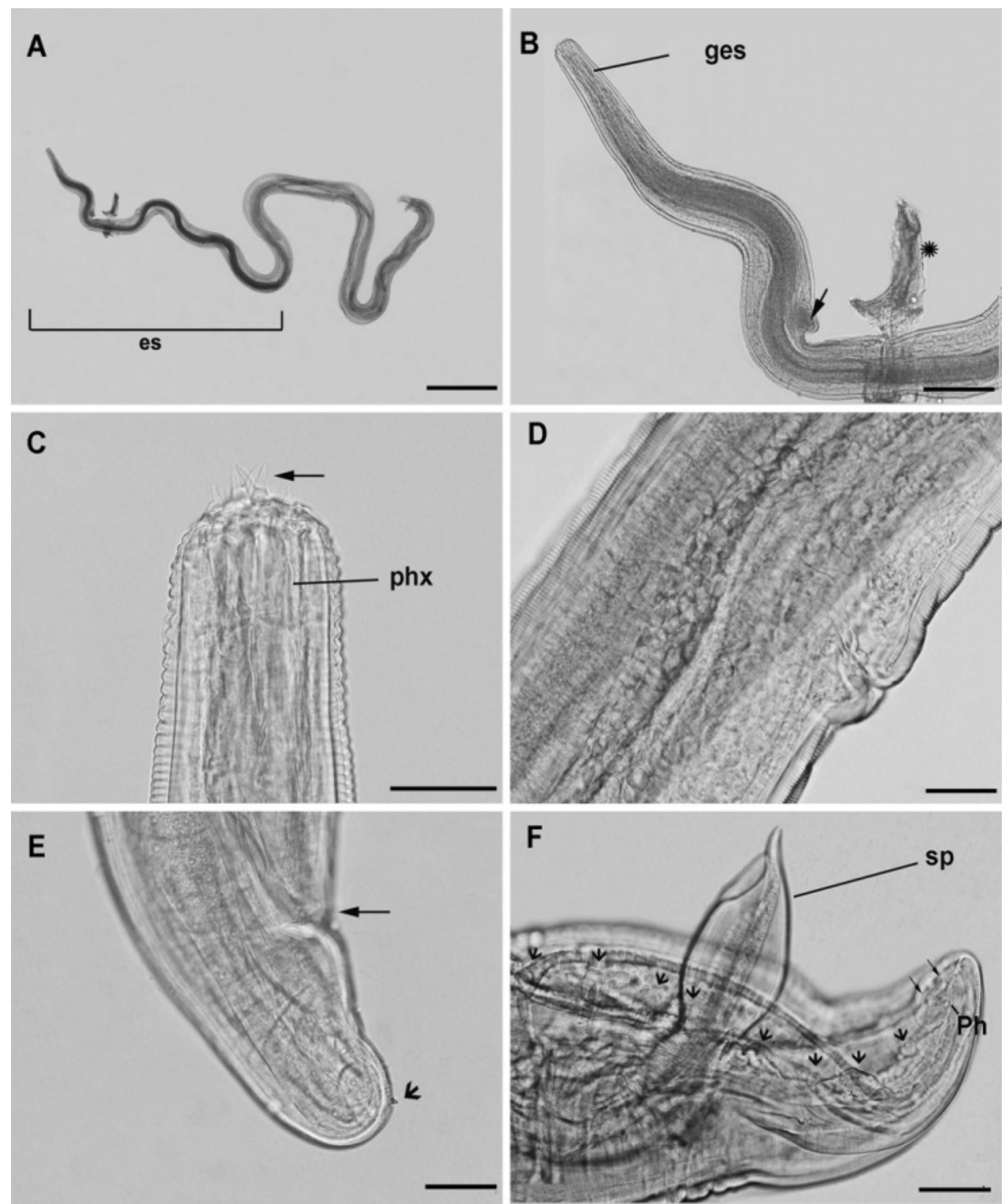

Fig. 1. Micrographs of Spirura carajaensis n. sp. a) Total view of the male body, highlighting the esophagus length (es). Bar: $1000 \mu \mathrm{m}$. b) Anterior region showing the glandular esophagus (ges), the position of the ventral boss (arrow), and the presence of tissue hopedeiro adhered to the body of the parasite (stars). Bar: $200 \mu \mathrm{m}$. c) Detail of the anterior region, showing the denticles (arrow) situated in the mouth and the pharynx (phx). Bar: $50 \mu \mathrm{m}$ d) Detail of the vulva aperture. Bar: $50 \mu \mathrm{m}$. e) Lateral view of the female posterior end, showing the anal aperture (arrow) and a mucrum in the final portion of the tail (arrowhead). Bar: $50 \mu \mathrm{m}$. f) Lateral view of the male posterior end, showing part of the copulatory bursa and the left spicule (sp) partially extruded, the 8 pairs of pedunculated caudal papillae (arrow head), 1 pair of sessile papillae (arrows) and the phasmids (Ph). Bar: $50 \mu \mathrm{m}$.

(Olympus, Tokyo, Japan) optical microscope equipped with a drawing tube (without zoom adjust). Photomicrographs were taken under an Olympus BX53 (Olympus, Tokyo, Japan) optical microscope with an image capturing system.

Eight nematode specimens were found in the esophagus of Proechimys roberti; however, only three males and one female were used for morphometric analysis under light microscopy. The other four specimens, comprising two males and two females, had been broken posteriorly to the ventral hump during removal from the host esophagus.

The measurements of the male specimens are organized as follows: lowest obtained values, highest obtained values and the means \pm standard deviation, with the last 2 presented between parentheses (all the values are in micrometers, except where indicated). For the female specimen, the absolute values are presented. 


\section{Results}

Spirura carajaensis n. sp.

(Figs. 1 - 2)

General diagnosis. Based on 3 adult males and 1 adult female. Stout cuticle with transversal striations. Mouth elongated dorsoventrally and ornamented with 6 bifid teeth, with 1 larger central pair and 2 smaller lateral pairs (Figs. 1a and 2b). Deirids anterior to the nerve ring, excretory pore posterior to the nerve ring. Pharynx followed by a long esophagus (Fig. 1b) clearly divided into a muscular anterior region and a glandular posterior region (Fig. 2a). Ventral hump (cuticular boss) at the end of the first third of the glandular esophagus (Figs. $1 \mathrm{~b}$ and $2 \mathrm{a}$ ). Conical tail with a small cuticular projection forming a caudal appendix in both sexes (Figs. $1 \mathrm{e}$ and $3 \mathrm{a}$ ). Male tails ornamented with 8 pairs of pedunculated papillae and 2 pairs of sessile papillae at the end of the tail, and a pair of phasmids lateral to the sessile papillae (Fig. 3a).

Males: $10-15 \mathrm{~mm}(12.6 \pm 2.7)$ in length; pharynx $56-72$ (64.9 \pm 8.1) long; larger denticles $19.5-23.4$ (22.1 \pm 2.2 ) and smaller denticles $13-14.3(13.4 \pm 0.7)$. Muscular regions of the esopha-
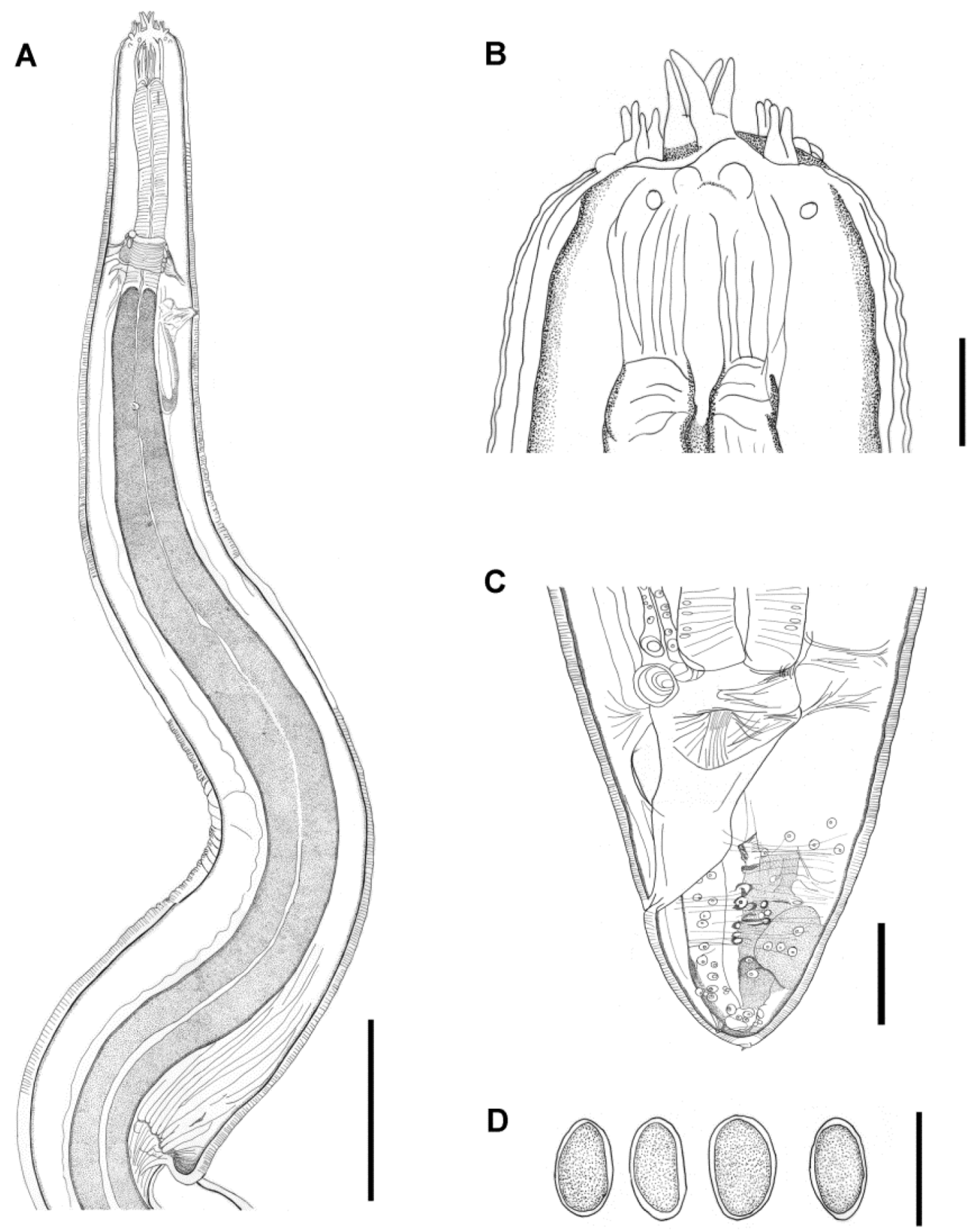

Fig. 2. Line drawings of Spirura carajaensis n. sp. a) Anterior end showing the limits between the glandular and muscular esophagus, nerve ring position, excretory pore and ventral boss. Bar: $100 \mu \mathrm{m}$. b) Details of the anterior end, showing the shape and disposition of the denticles. Bar: $25 \mu \mathrm{m}$. c) Lateral view of the female tail with the anal aperture and the small mucrum at the end of the tail. Bar: $100 \mu \mathrm{m}$. d) Eggs. Bar: $25 \mu \mathrm{m}$. 


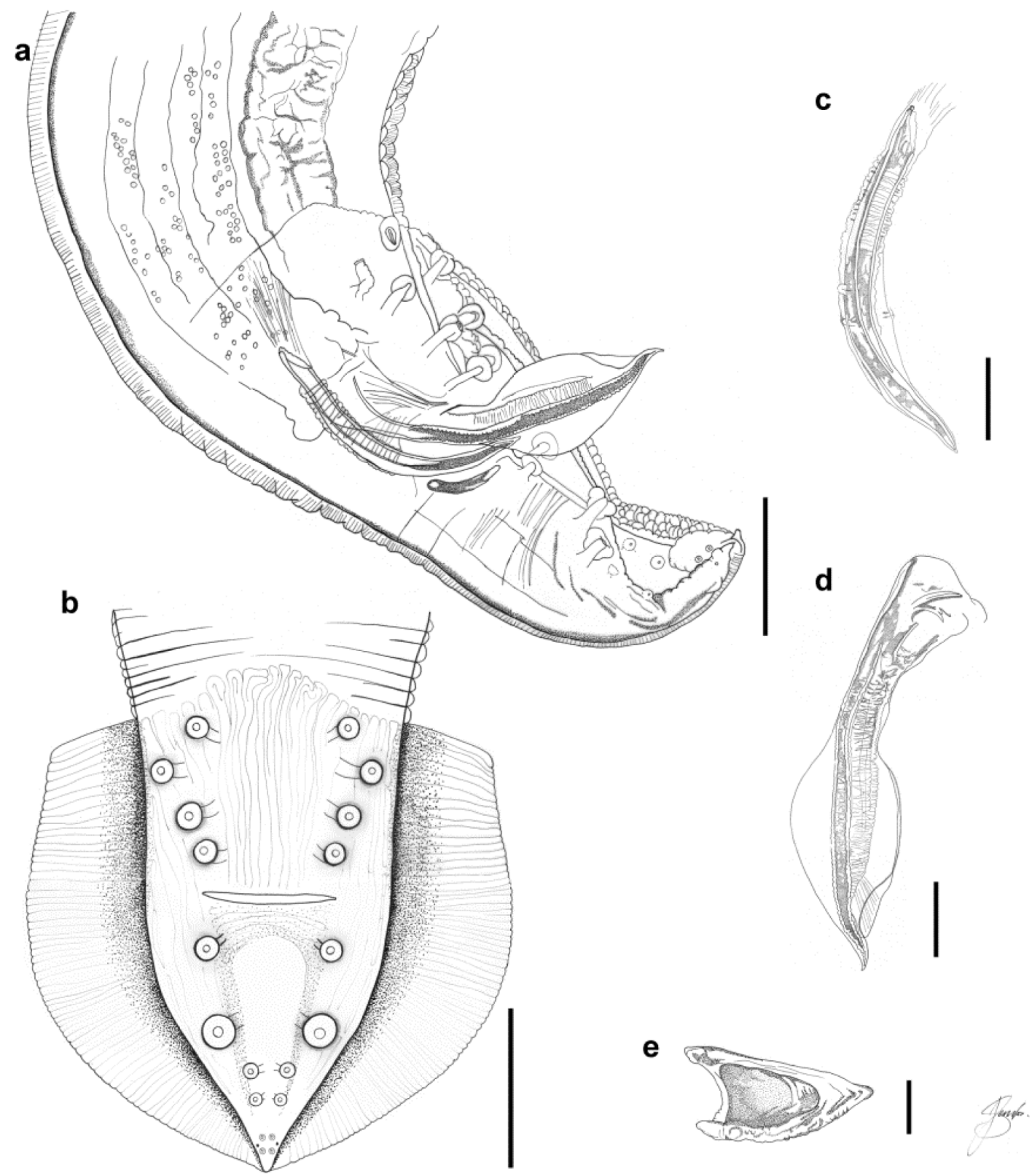

Fig. 3. Line drawings of the male posterior end of Spirura carajaensis n. sp. a) Lateral view of the copulatory bursa, showing the caudal alae, the papillae distribution and the spicules. Bar: $100 \mu \mathrm{m}$. b) Schematic drawing with ventral view of the copulatory bursa. Bar: $100 \mu \mathrm{m}$. c) Detail of the right spicule Bar: $50 \mu \mathrm{m}$. d) Detail of the left spicule. Bar: $50 \mu \mathrm{m}$. e) Detail of the gubernaculum. Bar: $50 \mu \mathrm{m}$.

gus measuring $221.3-304(258.7 \pm 41.9)$, and glandular regions measuring $4.2-4.4 \mathrm{~mm}(4.3 \pm 0.1)$ in length. Deirid, nerve ring and excretory pore at $150-250.7(200.3 \pm 71.8), 208-193.3$ $(242.7 \pm 44.8)$ and $344-426.7(372.4 \pm 47)$ from the anterior extremity, respectively. Ventral hump $0.9-1.4 \mathrm{~mm}(1.2 \pm 0.2)$ from the anterior extremity. Conical tail, elongated, strongly ventrally curved, with a well-developed caudal wing ornamented with 8 pairs of pedunculated papillae (4 pre-cloacal pairs and 4 postcloacal pairs) and 2 pairs of sessile papillae next to the caudal extremity (Figs. 1f, 3a and $3 \mathrm{~b}$ ). Unequal spicules, with the left spicule larger, measuring 301.3 - $344(319 \pm 22.3)$ in length $x 83.1$ -98.7 in width $(89.2 \pm 8.3)$, distinctly winged, with a well-developed foliar sheathe (Fig. 3d). Right spicule smaller and simpler (Fig. 3c) measuring $211.7-285.3(250.9 \pm 37.1) \times 20.8-32(25$ \pm 6.1). Triangular gubernaculum (Fig. 3e) measuring $39-61.3$ $(53.3 \pm 12.5) \times 13-48(38 \pm 18)$. Cloaca $261-280(271 \pm 13)$ from the posterior end.

Female: $19.5 \mathrm{~mm}$ in length; pharynx 101 long; larger denticles measuring 28 and smaller denticles measuring 15 in length. Muscular region of the esophagus measuring 317 and glandular region measuring $6.1 \mathrm{~mm}$. Deirid, nerve ring and excretory pore at 190 , 328 and 437 from the anterior extremity, respectively. Ventral hump positioned at $1.98 \mathrm{~mm}$ from the anterior extremity. Conical tail with rounded extremity and a small appendix (Figs. 1e and 2c). Vulva post-equatorial (Fig. 1d), $5.4 \mathrm{~mm}$ from the posterior region; tail 197 long; oviparous females. Eggs (Fig. 2d) measuring 15.6 - 26 (21.6 $\pm 4.5) \times 11.7-18.2(14.1 \pm 2.8)$. 
Taxonomic summary

Spiruridae Oerley, 1885

Spirura carajaensis n. sp.

Host: Proechimys roberti Thomas 1901.

Site of infection: esophagus

Locality: Tapirapé - Aquirí National Forest, Carajás Reserve,

Pará state, Brazil $\left(5^{\circ} 35^{\prime}\right.$ and $6^{\circ} 00^{\prime} S$ and $50^{\circ} 24^{\prime}$ and $\left.51^{\circ} 06^{\prime} \mathrm{W}\right)$.

Prevalence and intensity of infection: $22 \%$ (2 rodents infected / 9 rodents collected), $3-5$ (4.0 \pm 2.1 mean intensity).

Specimens deposited: Holotype male (MPEG №. 00033), allotype female (MPEG №. 00034), and 2 paratypes (2 males) (MPEG №. 00035).

Etymology: The name references the original locality of the hosts.

\section{Remarks}

The new species described in this study shows morphological characteristics common to the genus Spirura, according to Yamaguti (1961), Vicente et al. (1997) and Anderson et al. (2009), including an esophagus divided in 2 parts, a unique cuticular boss located next to the anterior extremity and the disposition of the caudal papillae.

According to Quetin and Krishnasamy (1975), the genus Spirura is divided into two groups. The first group comprises more primitive species that have $8-12$ pairs of pre-cloacal papillae, with the exemption of S. mounporti (Diouf et al., 2013), which has five pairs of pre-cloacal papillae. The second group is considered more evolved and has approximately 20 species, which have four pairs of pre-cloacal papillae. Our material corresponds to the second group.

Only four nematode species have been described to parasitize rodents of the Sciuridae family, and all of them were found in North America: Spirura infundibuliformis (McLeod, 1933), infecting Spermophilus tridecemlineatus; Spirura zapi (Erickson, 1938), infecting Zapus hudsonius hudsonius in Minnesota; Spirura leucurusi (Babero, 1973), a parasite of Ammospermophilus leucurus, and Spirura michiganensis (Sandground, 1935), described from Eutamias striatus lysteri in Michigan (PeraltaRodriguez et al., 2012). However, S. leucurusi, S. michiganensis and $S$. zapi are likely synonymous of $S$. infundibuliformis (Anderson et al., 1993). An important and common characteristic of the species described in North America is the presence of 8 to 12 pairs of pre-cloacal papillae (Sandground, 1935; Quetin and Krishnasamy, 1975; Peralta-Rodriguez et al., 2012).

In South America, there are only 2 species of the genus, which were described from mammalian hosts: Spirura guianensis, (Ortlepp, 1924; Chitwood, 1938) (= Spirura tamarini Cosgrove et al., 1963), a parasite of primates and marsupials, and Spirura delicata (Vicente et al., 1992), a parasite of Leontocebus mystax. Spirura carajaensis $\mathrm{n}$. $\mathrm{sp}$. that shows similarities to the morphological characteristics and biome habitat of Spirura guianensis regarding the shape and disposition of teeth-like projections and the caudal papillae distribution.

Among the 20 species of the genus, only S. dentata (Monnig, 1938), S. aurangabadensis (Ali and Lovekar, 1966) and S. guianensis display teeth-like formations on the apical region (Quetin and Krishnasamy, 1975). The new species has 3 pairs of bifid denticles in the oral opening, with the central pair larger than the lateral pairs, similar to what is found in S. guianensis. However, it is different from $S$. dentata, which has 3 non-bifid denticles of the same size, and $S$. aurangabadensis, which has bifid denticles of the same size.

Concerning the number and disposition of the caudal papillae, Spirura carajaensis n. sp. has 10 pairs; 4 pairs are pre-cloacal pedunculated papillae, 4 pairs are post-cloacal pedunculated papillae and 2 sessile pairs are at the end of the tail in addition to a pair of phasmids. This characteristic differs from the description of $S$. delicata, which has a total of 9 pairs of papillae, of which 4 pairs are pedunculated and pre-cloacal, 2 pairs are pedunculated and post-cloacal and 3 pairs are sessile on the tip of the tail (Vicente et al., 1992). There is no agreement regarding the number of caudal papillae in the description of $S$. guianensis. Ortlepp (1924) described 9 pairs: 4 pre-cloacal, 4 post-cloacal and 5 papillae on the tail extremity. Cosgrove et al. (1963) described 11 pairs: 4 pre-cloacal and pedunculated, 4 post-cloacal and pedunculated and 3 grouped sessile pairs. Quetin (1973) described 10 pairs with a single pre-cloacal papilla and a pair of phasmids between the last 2 pairs of caudal papillae. Amato et al. (1976) described 11 pairs: 4 pre-cloacal, 4 pedunculated and postcloacal and 3 grouped sessile pairs. The distribution and the number of papillae of $S$. carajaensis $n$. sp. are similar to $S$. guianensis as described by Quetin (1973). However, the new species do not have the single pre-cloacal papilla.

The size and shape of the spicule distinguishes Spirura carajaensis n. $\mathrm{sp}$. from the other species of the Spirura genus previously described in South America. The left spicule of $S$. carajaensis n. sp. is approximately $25 \%$ larger than its right spicule, similarly to the difference observed in S. guianensis, according to the description of Quetin (1973). However, according to the descriptions of Cosgrove et al. (1963) and Amato et al. (1976), S. guianensis has a right spicule slightly larger than the left spicule (difference of 17 to $19 \%)$. S. carajaensis also differs from S. delicata, which has a large asymmetry of the spicules (the right spicule is $65 \%$ bigger than the left spicule). In addition, neither S. guianensis nor S. delicata have a leaf-shaped sheath in the terminal half of the left spicule as observed in $S$. carajaensis $n$. sp.

The leaf-shaped sheathe in the terminal half of the spicule was only mentioned in the description of $S$. michiganensis and $S$. malayensis, a parasite of Tupaia in Malaysia (Quetin and Krishnasamy, 1975). However, S. michiganensis and S. malayensis differ from $S$. carajaensis n. sp. by not having bifid teeth and having only a $10 \%$ difference in length between their spicules.

In addition to the characteristics described before, a notably important morphological characteristic that distinguishes $\mathrm{S}$. carajaensis $\mathrm{n}$. $\mathrm{sp}$. from $S$. guianensis is the shape of the cuticular projections on the posterior extremity of the helminth. Female $S$. guianensis have 5 digit-shaped projections, while $S$. carajaensis n. sp. has a single digit-shaped projection both in the female and the male tail.

\section{Discussion}

The vertebrates originating from fauna surveys are important for the findings of local biodiversity; however, the parasite infracommunity is often neglected. Studies of parasites found in these vertebrates add data to helminth diversity without the need for performing euthanasia in new hosts. In summary, the data of the 
present study describe a new and first species of the genus Spirura, a parasite of rodents of Proechimys in the Brazilian Amazon. This parasite shows notable morphological characteristics that distinguish it from other species of the genus, such as the unique shape and proportions of the spicules and the presence of a unique digit-shaped caudal appendix in both sexes.

\section{Acknowledgements}

The authors thank the CAPES Foundation and the Ministry of Education of Brazil (Grants CAPES-PROCAD NF/2009, CAPES - PARASITOLOGIA BASICA/2010) PROPESP [Pró-Reitoria de Pesquisa e Pós-Graduação (Dean of Research and Postgraduate Studies)]; FADESP [Fundação de Amparo e Desenvolvimento da Pesquisa (Foundation for Research Development)]; FAPESPA [Fundação de Amparo à Pesquisa do Estado do Pará] - PRONEM 2013. We also thank the crew of the Laboratory of Cell Biology and Helminthology, "Profa. Dra. Reinalda Marisa Lanfredi", from the Universidade Federal do Para for their valuable assistance, and Lodney Nazaré Coelho for the assistance in obtaining the hosts. This study is part of the master dissertation of the first author from the Programa de Pos-Graduaçao em Biologia de Agentes Infecciosos e Parasitários/ICB-UFPA.

\section{References}

Anderson, R.C., Chabaud, A.G., Willmott, S. (Eds) Keys to the Nematode Parasites of Vertebrates. Archival volume. Wallingford, UK: CABI, pp. $361-382$

AMATO, J.F.R., CASTRO, P.T., GRISI, L. (1976): Sprirura guianensis (Ortlepp, 1924), parasita de Philander opossum quica (Temminck, 1825) no estado do Rio de Janeiro, Brasil (Nematoda, Spiruridae) [Sprirura guianensis (Ortlepp, 1924), parasite of Philander opossum quica (Temminck, 1825) in the state of Rio de Janeiro, Brazil (Nematoda, Spiruridae)]. Rev. Bras. Biologia, 36: $123-127$

Anderson, R.C., BARnes, E.T., BARTLett, C.M. (1993): Restudy of Spirura infundibuliformis McLeod, 1933 (Nematoda: Spiruroidea) from Spermophilus richardsonii, with observations on its development in insects. Can. J. Zool., 71: 1869 - 1873. DOI: 10.1139/z93-266

Barretto, A.C., Peterson, N.E., lago, E., Rosa, A.C., Braga, R.S.M., CubA, C.A.C, VeXenAt, J.A., MARSDEN, P.D. (1985): Leishmania mexicana in Proechimys iheringi denigratus Moojen (Rodentia, Echimyidae) in a region endemic for American cutaneous leishmaniasis. Rev. Soc. Bras. Med. Trop., 18: 243 - 246. DOI: 10.1590/S0037-86821985000400006
BONVICINO, C.R., OlIVEIRA, J.D., D'ANDREA, P.S. (2008): Guia dos roedores do Brasil, com chaves para gêneros baseadas em caracteres externos [Rodents of Brazil handbook, with keys to genus based in external characteristics]. Rio de Janeiro: Centro Pan-Americano de Febre Aftosa - OPAS/OMS, $120 \mathrm{pp}$.

Cosgrove, G.E., Nelson, B.M., Jones, A.W. (1963): Spirura tamarini sp. n. (Nematoda: Spiruridae) from an Amazonian primate, Tamarinus nigricollis (Spix, 1923). J. Parasitol., 49: 1010 1013. DOI: $10.2307 / 3275741$

DIOUF, M., SECK, C.A.B., BÂ, C.T., QUILICHINI, Y., MARCHAND, B. (2013): A New Species of Spirura Blanchard, 1849 (Nematoda: Spiruridae) Parasite of Heliosciurus gambianus and Xerus erythropus (Rodentia: Sciuridae) in Senegal. J. Parasitol., 99(6):1040 - 1044. DOI: 10.1645/12-86.1

ORTLEPP, R.J. (1924): On a collection of helminths from Dutch Guiana. J. Helminthol., 2: 15 - 40. DOI: 10.1017/S0022149X00002972 Peralta-Rodriguez, J.L., Caspeta-Mandujano, J.M., GueRERRO, J.A. (2012): A new spirurid (Nematoda) parasite from Mormoopid bats in Mexico. J. Parasitol., 98: 1006 - 1009. DOI: 10.1645/GE-2933.1

QUETIN, J.C. (1973): Présence de Spirura guianensis (Ortlepp, 1924) chez dês Marsupiaux néotropicaux. Cycle évolutif [Presence of Spirura guianensis (Ortlepp, 1924) in neotropical marsupials. Life cycle.]. Ann. Parasitol. Hum. Comp., 48: 117 - 133

QUETIN, J.C., KRISHNASAMY, M. (1975): Nématodes Spirura parasites dês Tupaia et du Nycticèbe en Malaisie. Ann. Parasitol. Hum. Comp., 50: $795-812$

SANDGROUND, J.H. (1935): Spirura michiganensis n. sp. and Rictularia halli $\mathrm{n}$. sp., two new parasitic nematodes from Eutamias striatus lysteri (Richardson). Trans. Am. Microsc. Soc., 54: 155 - 166. DOI: $10.2307 / 3222123$

VICENTE, J.J., PINTO, R.M., FARIA, Z. (1992): Spirura delicata sp. n. (Spiruridae, Spirurinae) from Leontocebus mystax (Callithrichidae) and a check list of other Nematodes of some brazilian primates. Mem. Inst. Oswaldo Cruz, 87, Suppl. 1: 305 - 308. DOI: 10.1590/S0074-02761992000500057

Vicente, J.J., Rodrigues, H.O., Gomes, D.C., Pinto, R.M. (1997): Nematóides do Brasil. Parte V: nematóides de mamíferos [Nematodes of Brazil, Part V: nematodes of mammals]. Rev. Bras. Zool., 14: 1 - 452

WeKSlER, M., BONVICINO, C.R., OTAZU, I.B., JUNIOR, J.S. (2001): Status of Proechimys roberti and P. oris (Rodentia: Echimyidae) from eastern Amazonia and central Brazil. J. Mammal., 82: 109 122. DOI: 10.1644/1545-1542(2001)082<0109:SOPRAP>2.0.CO;2 YAMAGUTI, S. (1961): Systema Helminthum. The Nematodes of Vertebrates. New York, NY: Interscience Publishers, 679 pp. 